\title{
Persistence of racial disparities in early-stage lung cancer treatment
}

\author{
Andrea Wolf, MD, ${ }^{\mathrm{a}, \mathrm{b}}$ Naomi Alpert, MS, ${ }^{\mathrm{c}}$ Benjamin V. Tran, MD, ${ }^{\mathrm{a}}$ Bian Liu, $\mathrm{PhD},{ }^{\mathrm{b}, \mathrm{c}}$ \\ Raja Flores, $\mathrm{MD},{ }^{\mathrm{a}, \mathrm{b}}$ and Emanuela Taioli, $\mathrm{MD}, \mathrm{PhD}^{\mathrm{a}, \mathrm{b}, \mathrm{c}}$
}

\section{ABSTRACT}

Objective: Although the incidence of lung cancer has decreased over the past decades, disparities in survival and treatment modalities have been observed for black and white patients with early-stage non-small cell lung cancer, despite the fact that surgical resection has been established as the standard of care. Possible contributors to these disparities are stage at diagnosis, comorbidities, socioeconomic factors, and patient preference. This study examines racial disparities in treatment, adjusting for clinicodemographic factors.

Methods: The Surveillance, Epidemiology, and End Results-Medicare dataset was queried to identify patients diagnosed with primary stage I non-small cell lung cancer between 1992 and 2009. Multivariable logistic regressions were performed to assess the association between race and treatment modalities within 1 year of diagnosis, adjusted for clinical and demographic factors. Adjusted Cox proportional hazards models were performed to evaluate disparities in survival, accounting for mode of treatment.

Results: We identified 22,724 patients; 21,230 (93.4\%) white and 1494 (6.6\%) black. Black patients were less likely to receive treatment (odds ratio $[\mathrm{OR}]_{\mathrm{adj}}$, $0.62 ; 95 \%$ confidence interval $[\mathrm{CI}], 0.53-0.73)$ and less likely to receive surgery only when treated $\left(\mathrm{OR}_{\mathrm{adj}}, 0.70,95 \% \mathrm{CI}, 0.61-0.79\right)$. Although univariate survival for black patients was worse, when accounting for treatment mode, there was no difference in survival (hazard ratio ${ }_{a d j}, 0.97 ; 95 \% \mathrm{CI}, 0.90-1.04$ for all patients, hazard ratio $_{\text {adj; }}, 0.98 ; 95 \%$ CI: 0.90-1.06 for treated patients).

Conclusions: Treatment disparities persist, even when adjusting for clinical and demographic factors. However, when black patients receive similar treatment, survival is comparable with white patients. ( $J$ Thorac Cardiovasc Surg

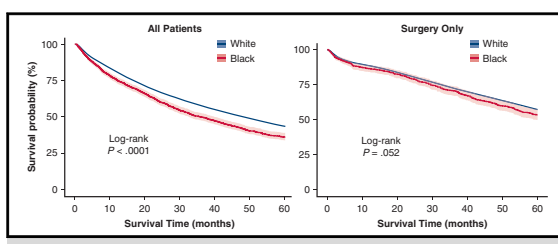

Survival for early stage lung cancer differed by race, but not when treated with surgery.

\section{Central Message}

Racial disparities persist in lung cancer treatment, even when adjusting for clinical and demographic factors. When black patients receive similar treatment, survival is comparable with white patients.

\section{Perspective}

We report on disparities in treatment and survival between black and white patients with early-stage non-small cell lung cancer, and analyze factors contributing to disparity in 22,724 patients. Black patients were less likely to receive treatment and to receive surgery only when treated. When accounting for treatment mode, there was no difference in survival.

See Commentary on page 1680 . 2019;157:1670-9)

Although the incidence of lung cancer has decreased over the past decades, disparities in survival and treatment have persisted among black and white patients with early-stage non-small cell lung cancer (NSCLC) with little change over this time period. ${ }^{1,2}$ These disparities have been attributed to a number of factors that may differ between black and white patients, including stage at diagnosis,

From the ${ }^{\mathrm{a}}$ Department of Thoracic Surgery, ${ }^{\mathrm{b}}$ Tisch Cancer Institute, and ${ }^{\mathrm{c}}$ Institute for Translational Epidemiology, Icahn School of Medicine at Mount Sinai, New York, NY.

This work was supported in part by the National Cancer Institute (P30CA196521).

Received for publication July 31, 2018; revisions received Nov 2, 2018; accepted for publication Nov 28, 2018; available ahead of print Jan 23, 2019.

Address for reprints: Emanuela Taioli, MD, PhD, One Gustave L. Levy Place, Box 1133, New York, NY 10029 (E-mail: Emanuela.Taioli@mountsinai.org).

0022-5223/\$36.00

Copyright (c) 2018 by The American Association for Thoracic Surgery

https://doi.org/10.1016/j.jtcvs.2018.11.108 socioeconomic and/or insurance status, access to care, patient preference, and rates of surgical treatment. ${ }^{3-8}$

Advances in the management of early-stage NSCLC have established surgical resection as the standard of care for operable patients. ${ }^{9,10}$ In addition, mediastinal lymph node staging has been associated with improved survival, and studies have demonstrated that the number of lymph nodes examined is positively associated with more accurate lung cancer staging. ${ }^{11,12}$ Studies have shown that black patients were less likely to receive surgical treatment and had shorter overall survival for early-stage

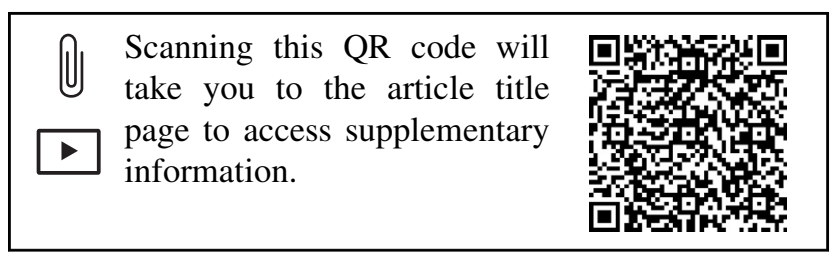




\section{Abbreviations and Acronyms \\ CI = confidence interval \\ CPT = Current Procedural Terminology \\ NSCLC $=$ non-small cell lung cancer \\ $\mathrm{OR}=$ odds ratio \\ $\mathrm{OR}_{\mathrm{adj}}=$ adjusted odds ratio \\ $\mathrm{RT}=$ radiation therapy \\ SEER = Surveillance, Epidemiology, and End Results}

NSCLC compared with white patients. ${ }^{8,13}$ When analyzing survival rates for the subset of patients treated with surgery, survival rates did not differ by race. ${ }^{8}$ Black patients undergoing surgical resection were less likely to undergo lymph node examination and had fewer lymph nodes examined compared with whites patients. ${ }^{12,14}$ No study to date has disentangled the effects of race, socioeconomic indicators, insurance, and clinical characteristics on treatment modalities in early-stage lung cancer.

We evaluated racial differences in treatment and survival of early-stage NSCLC for patients in the Surveillance, Epidemiology and End Results (SEER)-Medicare database, looking at trends stratified by treatment modality and era. The primary aims of this analysis were to identify racial disparities in treatment and to determine whether disparities in survival persisted when adjusting for confounding by treatment. Secondary aims were to examine racial disparities in node examination and reasons for not receiving surgery.

\section{METHODS \\ Data/Study Population}

The SEER-Medicare registry was queried for all patients with primary-stage I NSCLC diagnosed between 1992 and 2009. SEER encompasses $28 \%$ of the US population, with an estimated $93 \%$ of the registry linked to Medicare claims. ${ }^{15-17}$ Medicare insures $97 \%$ of patients older than 65 years old. Demographics (age at diagnosis, sex, race, marital status), cancer characteristics (histology, tumor size, and date of diagnosis), and information on pathologic lymph node examination were obtained from SEER. Medicare Provider Analysis and Review, outpatient, and physician claims (National Claims History) files were used to define cofactors not available or limited in SEER: Charlson comorbidity score, chemotherapy, extent of surgical resection, and radiation therapy (RT). The dataset is deidentified and therefore the study was exempt from institutional review board approval.

All black and white patients age 65 years and older whose first or only primary cancer was stage I pathologically confirmed NSCLC were identified $(n=41,431)$. Patients with missing date of diagnosis and those with a second primary cancer diagnosed within 1 year of the primary NSCLC diagnosis were excluded. Claims for comorbidity identification were available from 1991 and to allow for adequate follow-up after diagnosis, only patients diagnosed between 1992 and 2009 were included $(\mathrm{n}=36,740)$. Patients continuously enrolled in Medicare Part A and Part B and not a health maintenance organization for 1 year before and 1 year following diagnosis (or until death) were included $(\mathrm{n}=25,280)$. Patients missing key covariates (ZIP code-level socioeconomic data, marital status, comorbidities) were excluded, as these were few in number and the proportions only differed between races for marital status (14\% vs $9 \%)$ and comorbidity score ( $4 \%$ vs $3 \%$ ). This resulted in a cohort of 22,724 patients (Figure E1). The number of patients of other races (including non-black Hispanics, Asians, and others) was $6.6 \%$ of the overall sample and was dispersed among many treatment approaches, limiting the ability to draw meaningful conclusions, and thus the study was limited to the 2 largest race cohorts, black and white patients.

\section{Covariates}

In addition to basic demographics, median income for the ZIP code of residence and percent of adults 25 years or older with less than a high school diploma in the ZIP code of residence were extracted from SEER as a proxy of socioeconomic status, as SEER-Medicare does not contain individual level socioeconomic data or exact treatment location. Stage was defined using the third (1992-2003) and sixth (2004+) edition American Joint Committee on Cancer systems. Histology was classified according to the International Agency for Research on Cancer. ${ }^{18}$ All variables were measured at the time of diagnosis. As SEER includes only month and year of diagnosis, the date was recorded as the first of the month designated for each patient, to be able to capture all treatments that occurred in the month of diagnosis. All Medicare claims from the 12 months before the month of diagnosis were cross-referenced to calculate a Charlson comorbidity score for each patient (National Cancer Institute: Charlson Comorbidity macro, 2014 version). ${ }^{19}$

\section{Outcomes}

The primary outcomes were receipt of treatment and mortality. Receipt of treatment included cancer-directed surgery, radiation therapy (RT), and chemotherapy. RT and chemotherapy were identified using published algorithms $\mathrm{s}^{20,21}$ based on a combination of International Classification of Diseases, Ninth Revision, Clinical Modification diagnosis and procedure codes, Healthcare Common Procedure Coding System/Current Procedural Terminology (CPT) codes, and revenue center codes. Cancer-directed surgery was identified using the International Classification of Diseases, Ninth Revision, Clinical Modification procedure codes and CPT codes associated with lobectomy, sublobar resection, and pneumonectomy, supplemented by a published list of CPT codes associated with surgical resection ${ }^{22}$ (Table E1).

Overall survival was analyzed as lung cancer-specific survival was only available through SEER and follow-up was shorter for that dataset. Overall 5-year survival was calculated from date of diagnosis to date of death or last follow-up, whichever came first. The dataset was granted in 2013 with diagnoses complete through 2009, Medicare claims complete through 2010, and Medicare date of death complete through December 31, 2011.

Secondary outcomes were type of treatment and, among those who received surgery, lymph node examination, and number of lymph nodes examined. ${ }^{23}$ Recommendation of surgery and reasons for refusal of surgery were also analyzed. For patients who received surgery, the time until surgery was calculated as the number of days from the diagnosis until the date of admission to the hospital for surgery.

\section{Statistical Analysis}

Baseline characteristics were compared using $\chi^{2}$ tests for categorical variables and $t$ tests for continuous variables for the overall cohort and for the subset of patients who received treatment. Multivariable logistic regressions were used to assess for associations between race and treatment. The analysis was conducted for overall treatment (yes/no), and, among those treated, each treatment mode (yes/no): surgery only, RT only, chemotherapy only, and more than 1 treatment.

A single multinomial logistic regression was conducted among those who received treatment to assess the odds of receiving RT only, chemotherapy only, or more than 1 treatment, as compared with receiving 
surgery only, while adjusting for all other predictors. The possibility of an interaction between race and comorbidity score was explored by 2 methods: (1) conducting the multivariable analysis with and without inclusion of an interaction term for race and comorbidity score (race* comorbidity) for independent association with overall treatment and for surgery alone and (2) stratifying the analyses by comorbidity score $(0,1,2, \geq 3)$.

Univariate analyses and multivariable logistic regressions were used to assess the odds of the following (yes/no) in black versus white patients: lymph node examination among those who underwent surgery; $\geq 15$ lymph nodes examined among those with lymph node examination; surgery recommendation among all patients; and surgery refusal among those recommended surgery.

Overall 5-year survival of black and white patients was assessed using the Kaplan-Meier method, and Cox proportional hazards models were created to assess the independent association between race and survival, adjusted for treatment and other clinical and demographic factors. For variables that violated the proportional hazards assumption, an interaction with $\log$ of survival time was included in the model.

All multivariable models included the following covariates: sex, age at diagnosis, marital status, comorbidity score, tumor histology, tumor size, ZIP code-level income and education, and year of diagnosis, as these were considered clinically relevant and were significantly associated $(P<.05)$ with race or receipt of treatment. Because the socioeconomic variables were measured at ZIP code level, they were included in the multivariable analyses but individual effects of these variables were not reported. Models for all patients who underwent surgery also included type of surgery as a covariate. Statistical analysis was conducted using SAS software, version 9.4 (SAS Institute, Cary, NC).

\section{RESULTS}

There were 21,230 (93.4\%) white and $1494(6.6 \%)$ black patients. The median follow-up time was 34 months (range 0.1-60). On univariate analysis, black patients were younger, less often married, had greater comorbidity scores, lower median ZIP code-level income, greater ZIP codelevel percentage without high school diploma, and were more likely to have squamous cell carcinoma and larger tumor size (all $P<.0001$, Table 1). Similar differences were observed when the dataset was restricted to 20,555 patients $(19,306$ whites, 1249 blacks $)$ who received treatment (Table 2).

On multivariable analysis, black patients were significantly less likely to receive any treatment (adjusted odds ratio $\left[\mathrm{OR}_{\mathrm{adj}}\right], 0.62 ; 95 \%$ confidence interval $[\mathrm{CI}]$, $0.53-0.73, P<.0001$ ) (Figure $1, A$ ). Other factors independently inversely associated with treatment were age $\left(\mathrm{OR}_{\mathrm{adj}}, 0.79 ; 95 \% \mathrm{CI}, 0.68-0.91 ; \mathrm{OR}_{\mathrm{adj}}, 0.53 ; 95 \% \mathrm{CI}\right.$, 0.46-0.61; and $\mathrm{OR}_{\mathrm{adj}}, 0.28$; $95 \% \mathrm{CI}, 0.24-0.33$ for patients aged $75-79,80-84$, and $\geq 85$ years, compared with 65 69 years), marital status $\left(\mathrm{OR}_{\mathrm{adj}}, 0.59 ; 95 \% \mathrm{CI}, 0.53-0.65\right.$ for previously married, $\mathrm{OR}_{\mathrm{adj}}, 0.61 ; 95 \% \mathrm{CI}, 0.51-0.72$ for single, compared with married), nonadenocarcinoma histology $\left(\mathrm{OR}_{\mathrm{adj}}, 0.8,95 \% \mathrm{CI}, 0.72-0.89\right.$ for squamous cell; $\mathrm{OR}_{\mathrm{adj}}$, $0.48 ; 95 \% \mathrm{CI}, 0.41-0.57$ for large cell; and $\mathrm{OR}_{\mathrm{adj}}, 0.57 ; 95 \%$ CI, 0.49-0.65 for other, compared with adenocarcinoma) and tumor size $\left(\mathrm{OR}_{\mathrm{adj}}, 0.67 ; 95 \% \mathrm{CI}, 0.57-0.79\right.$; $\mathrm{OR}_{\mathrm{adj}}, 0.67$; $95 \% \mathrm{CI}, 0.53-0.84$ for tumors $51-70$ and $70+\mathrm{mm}$ vs tumors 0-20 mm) (Table E2).
TABLE 1. Description of the population under study

\begin{tabular}{|c|c|c|c|c|}
\hline Variable & $\begin{array}{c}\text { White } \\
(\mathrm{n}=\mathbf{2 1 , 2 3 0 )}\end{array}$ & $\begin{array}{r}\mathbf{B} \\
(\mathbf{n}= \\
\mathbf{n}\end{array}$ & $\begin{array}{l}\text { lack } \\
=1494) \\
(\%)\end{array}$ & $\begin{array}{c}P \\
\text { value* }^{*}\end{array}$ \\
\hline \multicolumn{5}{|l|}{ Treatment } \\
\hline No & $1924(9.06)$ & \multicolumn{2}{|c|}{245 (16.40) } & \multirow[t]{2}{*}{$<.0001$} \\
\hline Yes & $19,306(90.94)$ & 1249 & $(83.60)$ & \\
\hline \multicolumn{5}{|l|}{ Sex } \\
\hline Male & $10,494(49.43)$ & \multicolumn{2}{|c|}{728 (48.73) } & \multirow[t]{2}{*}{0.60} \\
\hline Female & $10,736(50.57)$ & 766 & $(51.27)$ & \\
\hline \multicolumn{5}{|l|}{ Age, y } \\
\hline $65-69$ & $4582(21.58)$ & \multicolumn{2}{|c|}{$451(30.19)$} & \multirow[t]{5}{*}{$<.0001$} \\
\hline $70-74$ & $6258(29.48)$ & 469 & $(31.39)$ & \\
\hline $75-79$ & $5655(26.64)$ & 313 & $(20.95)$ & \\
\hline $80-84$ & 3308 (15.58) & 191 & (12.78) & \\
\hline$\geq 85$ & $1427(6.72)$ & & (4.69) & \\
\hline \multicolumn{5}{|l|}{ Marital status } \\
\hline Single & $1178(5.55)$ & \multicolumn{2}{|c|}{$243(16.27)$} & \multirow[t]{3}{*}{$<.0001$} \\
\hline Married & $12,174(57.34)$ & \multicolumn{2}{|c|}{$557(37.28)$} & \\
\hline Previous marriage $\dagger$ & $7878(37.11)$ & \multicolumn{2}{|c|}{$694(46.45)$} & \\
\hline \multicolumn{5}{|l|}{ Charlson score } \\
\hline 0 & 8359 (39.37) & \multicolumn{2}{|c|}{$477(31.93)$} & $<.0001$ \\
\hline 1 & 6739 (31.74) & 433 & $(28.98)$ & \\
\hline 2 & $3232(15.22)$ & 245 & $(16.40)$ & \\
\hline$\geq 3$ & 2900 (13.66) & 339 & (22.69) & \\
\hline Histology & & & & \\
\hline Squamous & 7097 (33.43) & 592 & $(39.63)$ & $<.0001$ \\
\hline Adenocarcinoma & $10,367(48.83)$ & 634 & $(42.44)$ & \\
\hline Large cell & $1497(7.05)$ & 101 & $(6.76)$ & \\
\hline Other & 2269 (10.69) & 167 & (11.18) & \\
\hline Tumor size, mm & & & & \\
\hline $0-20$ & 6915 (32.57) & 442 & (29.59) & $<.0001$ \\
\hline $21-30$ & $6162(29.03)$ & 387 & $(25.90)$ & \\
\hline $31-50$ & $5712(26.91)$ & & $(29.52)$ & \\
\hline $51-70$ & $1683(7.93)$ & & $(9.91)$ & \\
\hline$\geq 71$ & $758(3.57)$ & & $(5.09)$ & \\
\hline Mean & $\begin{array}{l}\text { Standard } \\
\text { error }\end{array}$ & Mean & $\begin{array}{c}\text { Standard } \\
\text { error }\end{array}$ & \\
\hline $\begin{array}{l}\text { Median } \\
\quad \text { income, } \$ \ddagger\end{array}$ & 135.1 & $34,980.9$ & 374.6 & $<.0001$ \\
\hline $\begin{array}{l}\% \text { less than } \\
\text { high school } \ddagger\end{array}$ & 0.07 & 28.4 & 0.31 & $<.0001$ \\
\hline
\end{tabular}

$\overline{\text { Bold values indicate statistically significant results. }{ }^{*} \chi^{2} \text { test for categorical variables, }}$ $t$ test for continuous variables. † $†$ Divorced, separated, widowed. łZIP code level.

\section{Type of Treatment and Race}

On multivariable analysis of those who were treated, black patients were less likely to receive surgery only $\left(\mathrm{OR}_{\mathrm{adj}}, 0.70 ; 95 \% \mathrm{CI}, 0.61-0.79, P<.0001\right)$ and more likely to receive RT only $\left(\mathrm{OR}_{\mathrm{adj}}, 1.47 ; 95 \% \mathrm{CI}, 1.24-1.74\right.$, $P<.0001)$ or chemotherapy only $\left(\mathrm{OR}_{\mathrm{adj}}, 2.46 ; 95 \% \mathrm{CI}\right.$, 1.74-3.49, $P<.0001)$. There was no racial difference in the odds of receiving a combination of treatments $\left(\mathrm{OR}_{\mathrm{adj}}\right.$ for black patients, $1.06 ; 95 \% \mathrm{CI}, 0.91-1.23, P=.4482$ ) 
TABLE 2. Characteristics of patients who received treatment

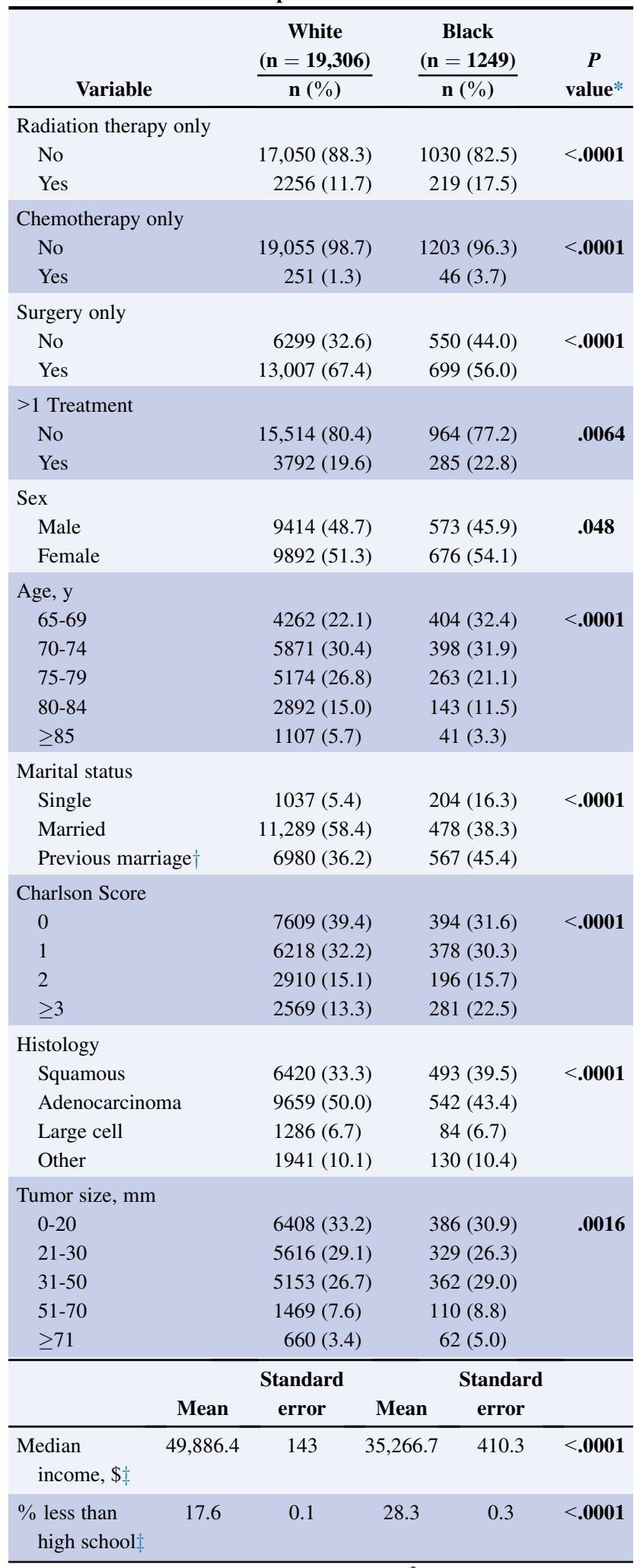

Bold values indicate statistically significant results. $* \chi^{2}$ test for categorical variables,

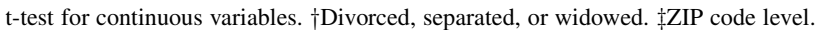

(Figure 1, A, Table 3, Tables E3-E5). A similar direction of the associations was observed when the data were stratified according to year of diagnosis (Figure 1, $B$ ) or according to number of comorbidities (data not shown). Among patients who received surgery or had documentation that it was recommended $(\mathrm{n}=22,658)$, black patients were significantly less often offered surgery $\left(\mathrm{OR}_{\mathrm{adj}}, 0.75 ; 95 \% \mathrm{CI}, 0.65\right.$ $0.86)$. Other factors independently associated with not being recommended surgery on multivariable analysis were older age, nonmarried status, greater comorbidity score, nonadenocarcinoma histology, and larger tumor size. Among patients who were offered surgery $(\mathrm{n}=18,313)$, black patients were significantly more likely than white patients to refuse surgery $\left(\mathrm{OR}_{\mathrm{adj}}, 1.98 ; 95 \% \mathrm{CI}, 1.40-2.81\right)$. Other factors independently associated with refusal of surgery on multivariable analysis were older age, nonmarried status, greater comorbidity score, nonadenocarcinoma histology, and larger tumor size. Among those who received surgery, there was no difference in the median time until surgery on univariate analysis (36 days in white patients vs 37 days in black patients, $P=.3244$ ).

In patients who were treated with surgery and had known status regarding node examination $(\mathrm{n}=16,629)$, there was no association between race and pathologic node examination (yes/no) $\left(\mathrm{OR}_{\mathrm{adj}}, 1.12 ; 95 \% \mathrm{CI}, 0.91-1.39\right)$ in black versus white patients on multivariable analysis. Among patients who underwent surgery, black patients were more likely than white patients to undergo sublobar resection (Video 1), and there was a significant independent association between receiving a sublobar resection and lack of node examination, compared with lobectomy $\left(\mathrm{OR}_{\mathrm{adj}}\right.$, $0.11 ; 95 \% \mathrm{CI}, 0.10-0.13)$. Other factors significantly independently inversely associated with node examination on multivariable analysis were increased age, nonmarried status, greater comorbidity score, and large cell or other histology; larger tumor size was positively associated with node examination.

In those with node examination $(\mathrm{n}=14,161)$, there was a significant independent association between race and more nodes examined $\left(\mathrm{OR}_{\mathrm{adj}}, 0.81 ; 95 \% \mathrm{CI}, 0.68-0.98\right.$ for $\geq 15$ vs $<15$ nodes examined) in black versus white patients. There was a significant independent association between sublobar resection (vs lobectomy) and fewer number of nodes examined $\left(\mathrm{OR}_{\mathrm{adj}}, 0.76 ; 95 \% \mathrm{CI}, 0.68-0.84\right.$ for $\geq 15$ nodes examined). Nonmarried status and greater comorbidity score were independently inversely associated, whereas larger tumor size was independently positively associated with more nodes examined.

On multivariable analysis, black race was associated with greater odds of being treated with RT alone $(P<.0001)$, chemotherapy alone $(P<.0001)$, or a combination of treatments $(P=.0077)$, compared with surgery alone (Figure 2 ). 

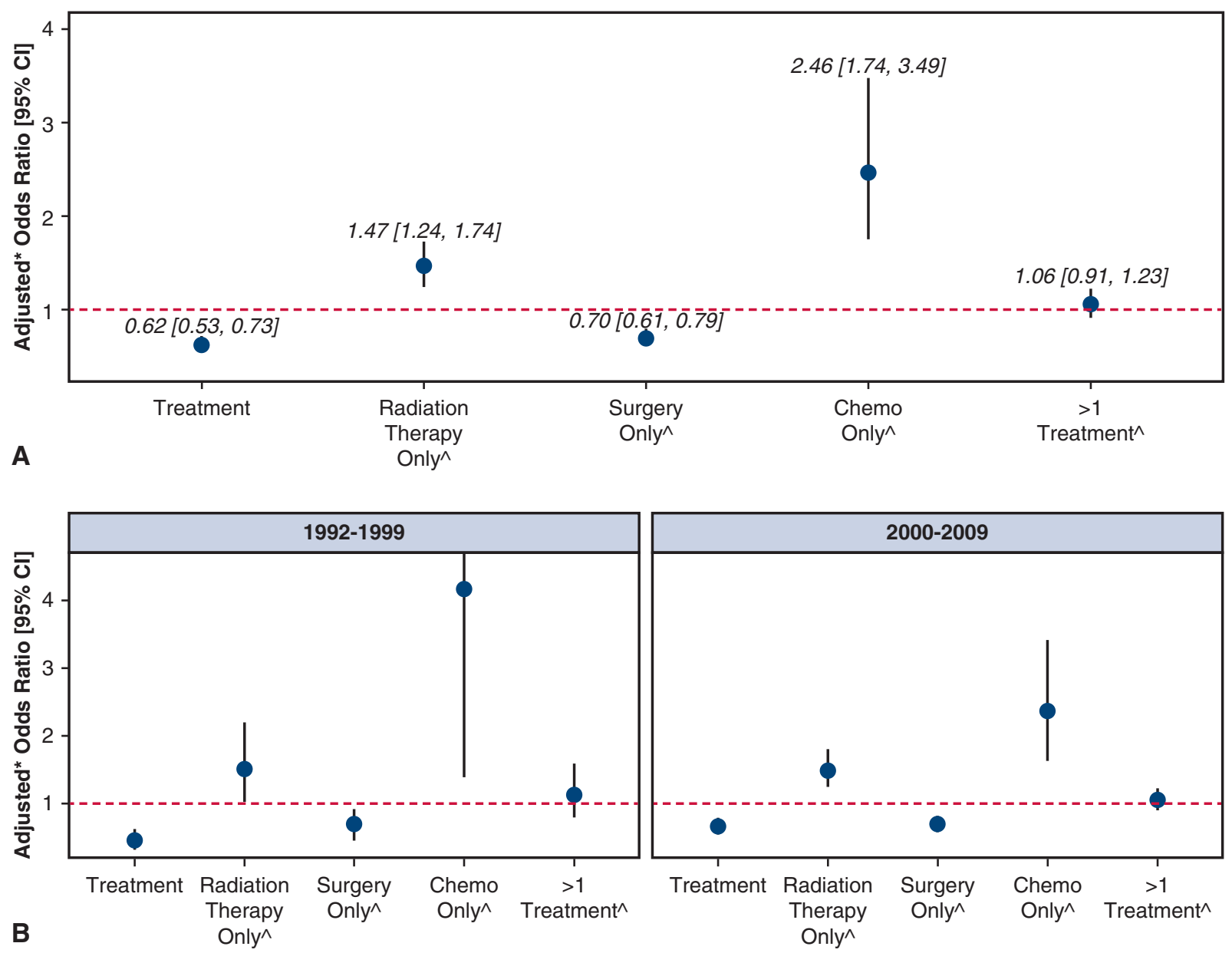

$\wedge$ Among Treated Patients

*Adjusted for gender, age, marital status, comorbidity score, histology, tumor size, ZIP code socioeconomic variables, year of diagnosis

FIGURE 1. Adjusted odds of treatment in black versus white patients by treatment category (A) overall and (B) stratified by year of diagnosis (1992-1999 and 2000-2009). For individual treatment categories, patients who did not undergo any treatment were excluded. CI, Confidence interval.

Other factors independently associated with receipt of RT alone on multivariable analysis were female sex, older age, nonmarried status, greater comorbidity score, nonadenocarcinoma histology, and larger tumor size. Factors independently associated with receipt of chemotherapy alone were older age, nonmarried status, greater comorbidity score, nonadenocarcinoma histology, and larger tumor size. Factors independently associated with receipt of more than 1 treatment were younger age, greater comorbidity score, larger tumor size, and nonadenocarcinoma histology (Table E6).

To evaluate for potential nonmeasured confounders, a subset analysis was conducted comparing patients who were treated with those who were not, stratified by race. For both races, male sex, older age, and unmarried status were associated with not being treated. For white patients, additional cofactors associated with no treatment were greater comorbidity score, nonadenocarcinoma histology, increased tumor size, and both ZIP code socioeconomic variables. The race*comorbidity score interaction term was not significant in the multivariable model for either overall treatment or surgery $(P=.3954$ and $P=.3392$, respectively), nor was it significant in the multinomial logistic regression model for all treatments $(P=.1567)$. When stratified by comorbidity score, trends remained similar across scores.

\section{Survival}

Univariate overall 5-year survival was lower for black than for white patients (Figure 3). When stratified by treatment type, however, those differences were not significant (Figure 4, $A-D$ ). When adjusted for confounding and accounting for mode of treatment, there was no significant association between race and overall survival; the hazard 
TABLE 3. Univariate and multivariable odds of receipt of surgery alone (yes vs no), among treated patients

\begin{tabular}{|c|c|c|}
\hline Variable & $\frac{\text { Univariate }}{\text { OR }(95 \% \text { CI })}$ & $\frac{\text { Multivariable }}{\text { OR }^{*}(95 \% \text { CI })}$ \\
\hline \multicolumn{3}{|l|}{ Race } \\
\hline White & 1.00 (Ref) & 1.00 (Ref) \\
\hline Black & $0.62(0.55-0.69)$ & $0.70(0.61-0.79)$ \\
\hline \multicolumn{3}{|l|}{ Sex } \\
\hline Male & 1.00 (Ref) & $1.00(\operatorname{Ref})$ \\
\hline Female & $1.12(1.06-1.19)$ & $0.98(0.92-1.05)$ \\
\hline \multicolumn{3}{|l|}{ Age, y } \\
\hline $65-69$ & 1.00 (Ref) & 1.00 (Ref) \\
\hline $70-74$ & $0.97(0.89-1.05)$ & $0.98(0.90-1.07)$ \\
\hline $75-79$ & $0.97(0.89-1.05)$ & $1.02(0.93-1.12)$ \\
\hline $80-84$ & $0.75(0.68-0.82)$ & $0.82(0.74-0.91)$ \\
\hline$\geq 85$ & $0.40(0.35-0.46)$ & $0.45(0.39-0.52)$ \\
\hline \multicolumn{3}{|l|}{ Marital status } \\
\hline Married & 1.00 (Ref) & 1.00 (Ref) \\
\hline Single & $0.85(0.75-0.96)$ & $0.93(0.82-1.07)$ \\
\hline Previous marriage $\dagger$ & $0.87(0.82-0.93)$ & $0.95(0.88-1.02)$ \\
\hline \multicolumn{3}{|l|}{ Charlson score } \\
\hline 0 & $1.00(\operatorname{Ref})$ & 1.00 (Ref) \\
\hline 1 & $0.73(0.68-0.79)$ & $0.74(0.68-0.80)$ \\
\hline 2 & $0.66(0.61-0.72)$ & $0.71(0.65-0.78)$ \\
\hline$\geq 3$ & $0.54(0.49-0.59)$ & $0.60(0.54-0.66)$ \\
\hline \multicolumn{3}{|l|}{ Histology } \\
\hline Adenocarcinoma & 1.00 (Ref) & 1.00 (Ref) \\
\hline Squamous & $0.59(0.55-0.63)$ & $0.72(0.67-0.77)$ \\
\hline Large cell & $0.40(0.35-0.45)$ & $0.42(0.37-0.47)$ \\
\hline Other & $0.29(0.26-0.32)$ & $0.36(0.33-0.40)$ \\
\hline \multicolumn{3}{|l|}{ Tumor size, mm } \\
\hline $0-20$ & 1.00 (Ref) & 1.00 (Ref) \\
\hline $21-30$ & $0.59(0.55-0.64)$ & $0.60(0.55-0.65)$ \\
\hline $31-50$ & $0.36(0.33-0.39)$ & $0.37(0.34-0.41)$ \\
\hline $51-70$ & $0.24(0.22-0.27)$ & $0.24(0.22-0.27)$ \\
\hline$\geq 71$ & $0.21(0.18-0.25)$ & $0.20(0.17-0.24)$ \\
\hline
\end{tabular}

$\mathrm{N}=20,555$. OR, Odds ratio; $C I$, confidence interval. *Adjusted for all listed variables, ZIP code level socioeconomic status variables, and year of diagnosis. $\dagger$ Divorced, separated, or widowed.

ratio $_{\text {adj }}$ for black patients was 0.97 (95\% CI, 0.90-1.04) and hazard ratio $_{\text {adj }}, 0.98$ (95\% CI, 0.90-1.06) among patients who received treatment. When multivariable models were stratified by treatment mode, there was no significant difference in survival for black and white patients (Table E7). The analysis was repeated using lung-cancer specific survival and results were similar (data not shown).

\section{DISCUSSION}

This study evaluated highlighted the racial disparities in the treatment of stage I NSCLC in a large series of patients: black patients with stage I NSCLC were less likely to receive surgery and more likely to be treated with RT and/or chemotherapy, frequently when the latter has not been considered standard of care. These differences were seen on univariate analysis and after adjustment for confounders

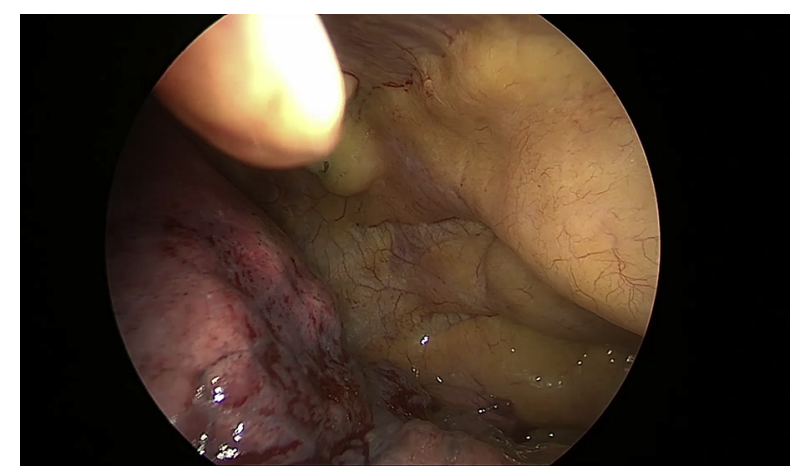

VIDEO 1. Left VATS lower-lobe wedge resection (a form of sublobar resection) and mediastinal lymph node sampling for a biopsy-proven left lower lobe adenocarcinoma in a patient with history of Bentall procedure for ascending aortic aneurysm and contralateral genetically different synchronous lung adenocarcinomas who had previously undergone right VATS upper and lower lobe wedge resections, mediastinal lymph node dissection and subsequent endobronchial ultrasound for preoperative lymph node staging. A single slice of the preoperative computed tomography of the chest is shown at the start depicting the right lower lobe staple line (arrow) and the biopsy-proven metachronous left lower lobe adenocarcinoma (circle). VATS, Video-assisted thoracoscopic surgery. Video available at: https://www.jtcvs.org/article/S0022-5223(18)33258-6/fulltext.

that may have affected the choice of treatment, such as comorbidities and age. The SEER-Medicare dataset did not include details as to why individual patients received specific treatments (or no treatment), and the reason for receiving chemotherapy and/or radiation may have been miscoding as stage I, adjuvant chemotherapy for large tumors, or receipt of nonstandard treatment, but these are all factors that should not be related to race. Despite publication of a landmark paper highlighting racial disparities in $1999,{ }^{8}$ no progress has occurred to improve the rate of appropriate therapy for black patients, as shown in Figure 1. Similar results were demonstrated in a previous study by our group ${ }^{24}$ and subsequently by others $^{25,26}$ using the SEER registry and the Veterans Affairs database. ${ }^{27-29}$ More detailed comorbidity information in the SEER-Medicare database enabled the current study to conduct a more comprehensive adjustment for confounding, thus limiting selection bias due to comorbidities that might contraindicate surgery.

The persistent lower rate of delivery of standard of care to black patients with lung cancer may result from hospital and patient-level factors, such as vulnerable socioeconomic status, lack of access to experienced surgeons/centers, misconceptions about surgery, and/or lack of adequate insurance coverage. ${ }^{30}$ A large study ${ }^{13}$ of 473,722 patients with cancer from the SEER database showed that those with Medicaid coverage or without insurance were more likely to present with advanced disease, were less likely to receive cancer-directed surgery and/or RT, and had lower 


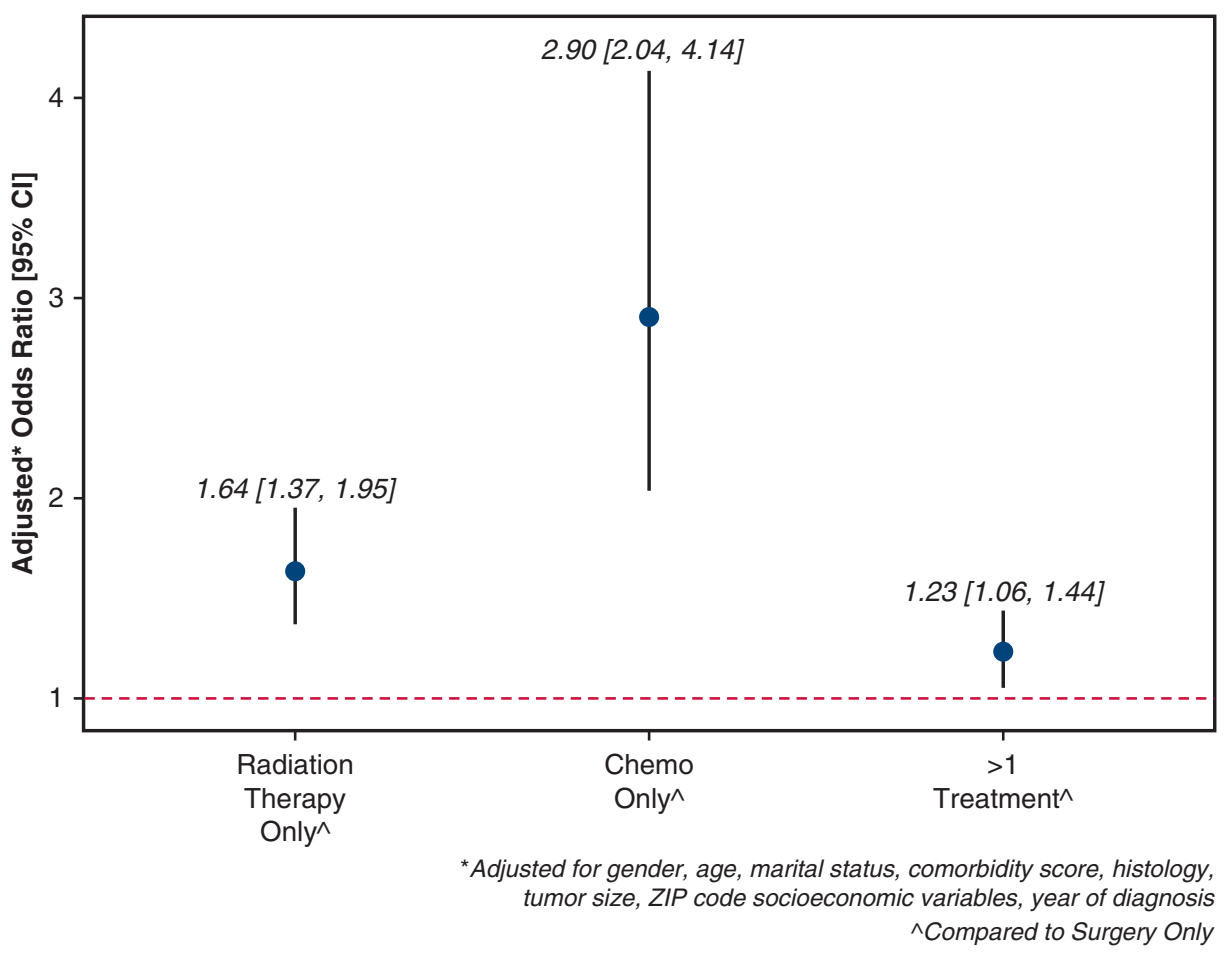

FIGURE 2. Adjusted relative odds of treatment, compared with surgery only in black versus white patients. $C I$, Confidence interval.

survival. A systematic review of insurance status and lung cancer outcome ${ }^{5}$ reported that patients with Medicaid or no insurance had worse outcomes; were diagnosed at a later stage; and were less likely to undergo treatment with surgery or RT, to be treated at a high-volume center, and/or to receive guideline-concordant care than those with private insurance. Although these findings were important, neither study evaluated the role of race, interaction with insurance status, and the independent effect of race on outcomes. Our analysis independently evaluated patients covered by Medicare and, similar to the Veterans Affairs data, ${ }^{27-29}$ included patients covered by a single insurer, thus attenuating the contribution of type of insurance coverage to the disparities in treatment observed. Still, other

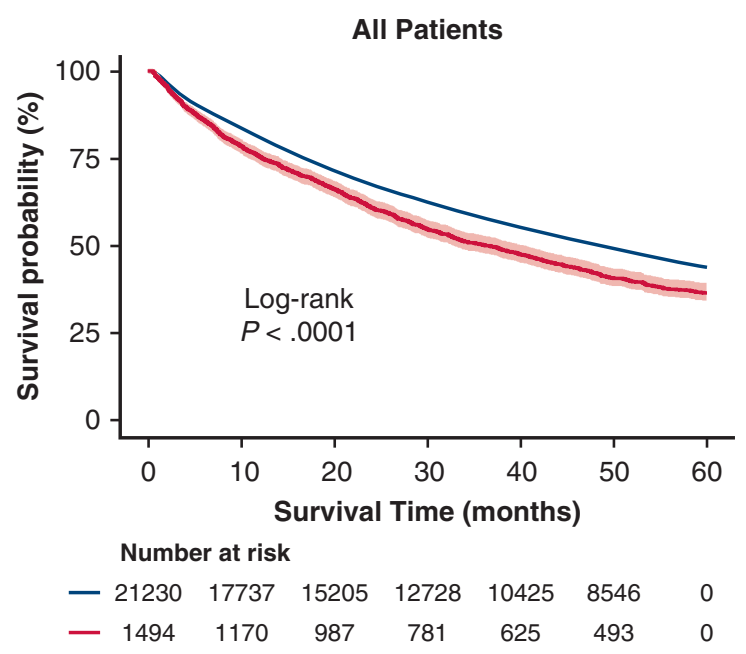

A

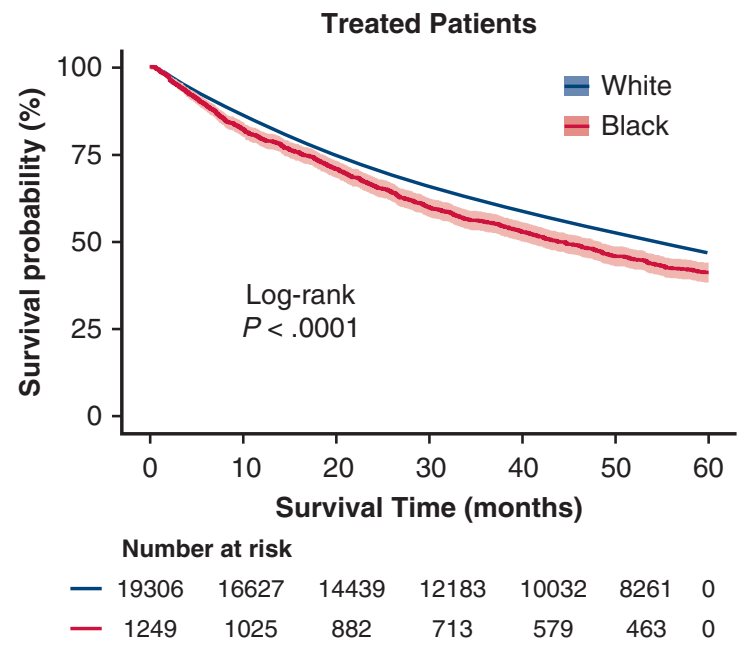

B

FIGURE 3. Five-year survival for black (red line) and white (blue line) patients for (A) all patients and (B) treated patients. 


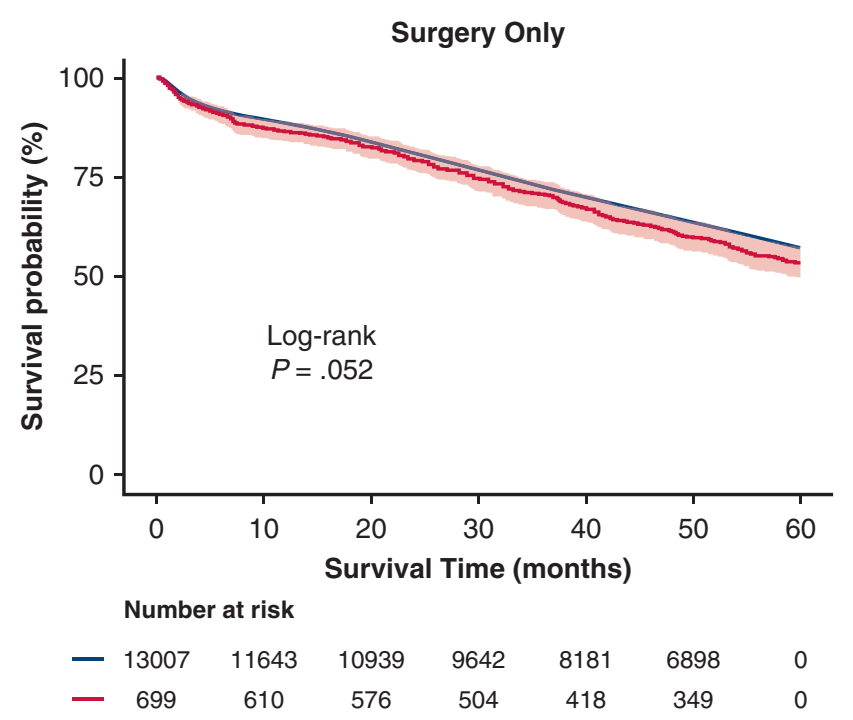

A

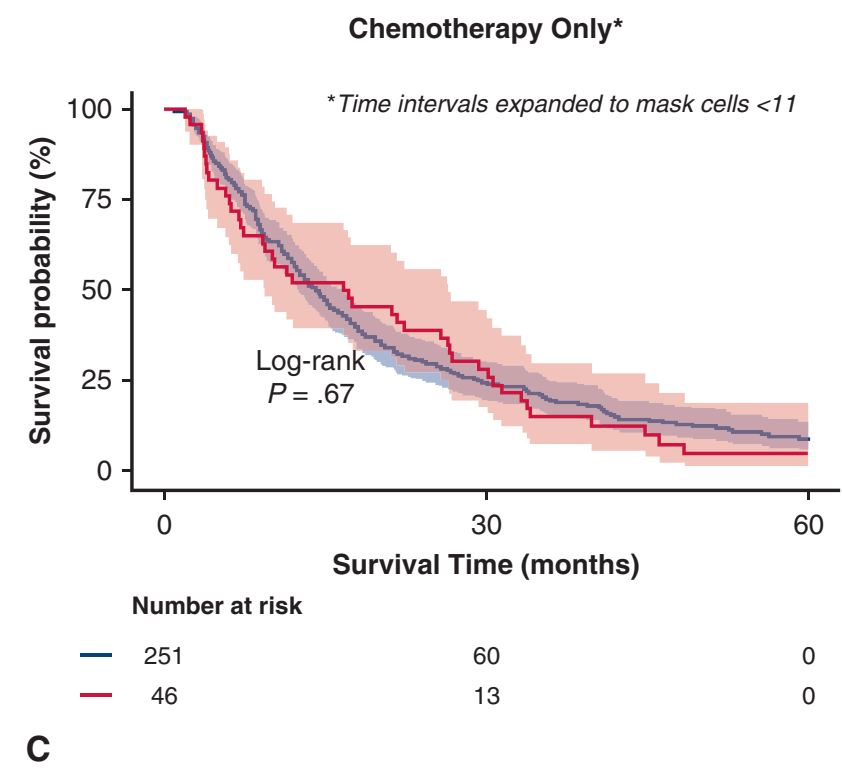

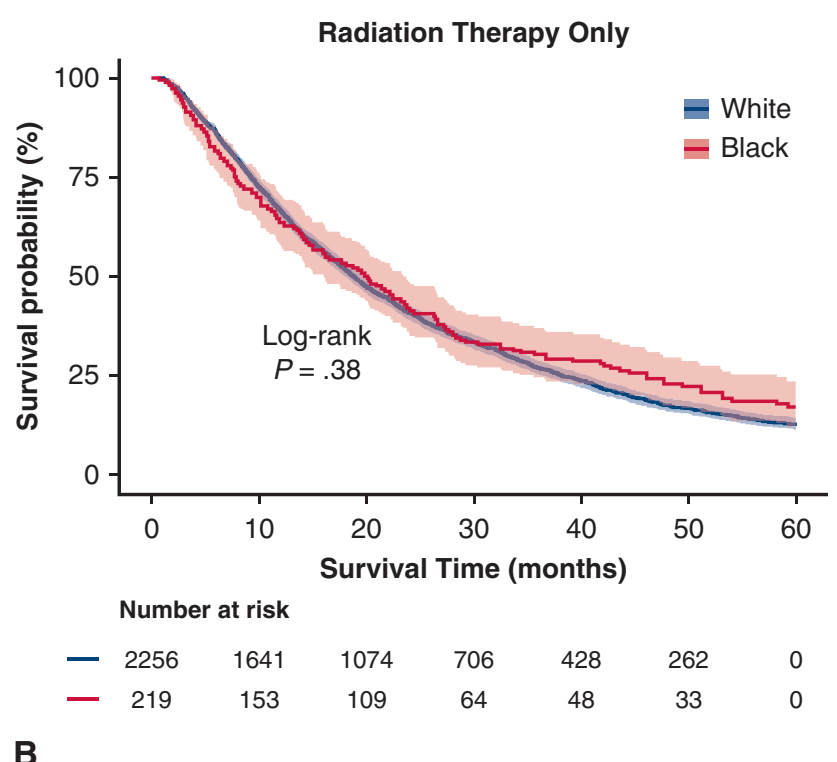

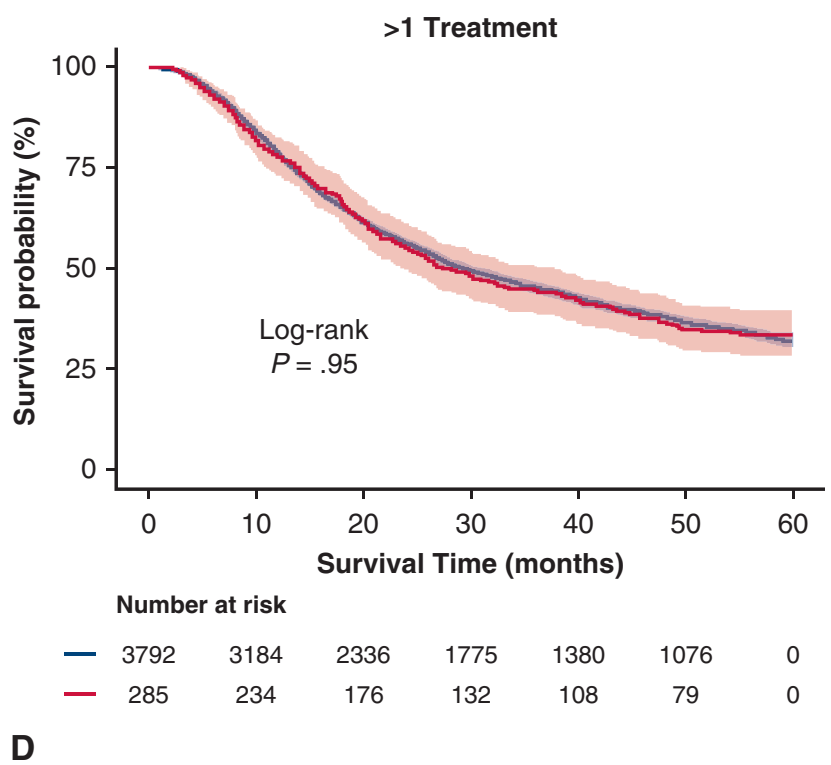

FIGURE 4. Five-year survival for black (red line) and white (blue line) patients for (A) patients undergoing surgery only, (B) radiation therapy only, (C) chemotherapy only, and (D) $>1$ treatment. For $(C)$, time intervals were expanded to mask cells with $<11$ events.

financial factors, such as copayment, ability to take off of work, and other noncovered cancer care costs, may have contributed to treatment disparities. ${ }^{30}$

It is possible that racial disparities in appropriate treatment were affected by disparities in patient-surgeon interaction. In our analysis, black patients were less likely to be offered surgery, and among those who were recommended surgery, there was a greater rate of patient refusal. Tohme and colleagues ${ }^{31}$ reported similar results for earlystage pancreatic cancer using the National Cancer Data Base, finding an independent association between African American race and refusal of surgery on multivariable analysis. The current study corroborated a SEER analysis by Mehta and colleagues ${ }^{4}$ evaluating stage I and II NSCLC patients diagnosed between 1988 and 2002, in which black race was associated with greater odds of refusing surgery, adjusted for confounders. Further exploration of barriers to appropriate treatment in black patients with lung cancer is needed.

The current study also noted racial differences in surgery and lymph node evaluation. Black patients were more likely than white patients to undergo sublobar resection instead of lobectomy, as previously reported by our group. ${ }^{32}$ Sublobar resection was associated with lower rates of nodal 
examination in general and, among those with nodes examined, fewer nodes evaluated. More importantly, black race was independently associated with lower likelihood of having 15 nodes or more sampled, even when adjusted for extent of surgery. Osarogiagbon and colleagues ${ }^{33}$ analysis of the SEER dataset found similar racial disparities. As lymph node staging and number of nodes examined may have impact on prognosis and survival, ${ }^{33,34}$ these differences may result in racial disparities in survival, although no such survival differences were found in our study for patients treated surgically. In the current study, among patients who underwent surgery, there was no significant difference in rate of lymph node staging related to race, similar to the conclusion of a retrospective analysis of NSCLC resections in the SEER database from 1998 to $2009 .^{34}$

When long-term survival was assessed, there were no differences between black and white patients, as treatment was included in the adjusted models. This underscores the importance of providing appropriate care for all patients. When black patients with stage I NSCLC were treated with surgery (standard of care for operative candidates), survival was similar for both races. Other studies ${ }^{25}$ have had different results, but relied on SEER without linkage to Medicare, and analysis may have been confounded by insurance status and presence of comorbidities.

Although the strengths of this study are the homogenous insurance status and more comprehensive adjustment for confounders, there are several limitations. Important variables not available in SEER-Medicare included pulmonary function tests, academic/community status of the hospital, institution annual lung resection volume, and specialized (thoracic) training of the surgeon performing surgery. In addition, stage reported in SEERMedicare was based on pathologic stage when available, and clinical stage when it was not. This allowed for the possibility of understaging among patients not treated with surgery. As fewer black patients were treated with surgery, this may have partly confounded the univariate difference in survival. Assuming that some percentage of patients not receiving surgery may have had more advanced stage despite being clinically diagnosed as stage I, these patients were still offered therapies not currently considered standard of care for most patients with stage I lung cancer, and the existence of racial disparities in this regard is disturbing. Another limitation of the study was that there were disproportionately more black patients missing comorbidity score and/or marital status and therefore not included in the analysis. Although this may have biased the results if these patients were not representative of the rest of the cohort, the effect was likely small, given small percentages of the total sample and the effects observed for most outcomes still warrant attention.
Despite these limitations, the data and analysis of the current study of 22,724 patients demonstrated important findings. Despite nearly 2 decades of progress in cancer care since a landmark study highlighting racial disparities in lung cancer treatment, black patients still received a lower rate of appropriate treatment for stage I lung cancer. When provided equal treatment, there were no racial disparities in survival. Further evaluation of the socioeconomic, cultural, and possible bias-related causes of these differences must be evaluated to understand and reduce racial disparities to improve lung cancer care for all patients.

\section{Conflict of Interest Statement}

Authors have nothing to disclose with regard to commercial support.

This study used the linked SEER-Medicare data base. The interpretation and reporting of these data are the sole responsibility of the authors. The authors acknowledge the efforts of the Applied Research program, National Cancer Institute; the Office of Research, Development and Information, Centers for Medicare \& Medicaid Services; Information Management Service, and the Surveillance, Epidemiology and End-Results (SEER) Program tumor registries in the creation of the SEER-Medicare database. The authors thank Mr Larry Adel for patience and assistance with editing the video associated with this manuscript.

\section{References}

1. Siegel RL, Miller MD, Jemal A. Cancer statistics, 2018. CA Cancer J Clin. 2018; 68:7-30.

2. Noone AM, Howlader N, Krapcho M, Miller D, Brest A, Yu M, et al, eds. SEER Cancer Statistics Review, 1975-2015, National Cancer Institute. Bethesda, MD. Available at: https://seer.cancer.gov/csr/1975_2015/, based on November 2017 SEER data submission, posted to the SEER web site, April 2018. Accessed July $31,2018$.

3. Esnaola NF, Gebregziabher M, Knott K, Finney C, Silvestri GA, Reed CE, et al. Underuse of surgical resection for localized non-small cell lung cancer among whites and African Americans in South Carolina. Ann Thorac Surg. 2008;86: 220-7.

4. Mehta RS, Lenzner D, Argiris A. Race and health disparities in patient refusal of surgery for early-stage non-small cell lung cancer: a SEER cohort study. Ann Surg Oncol. 2012;19:722-7.

5. Slatore CG, Au DH, Gould MK, American Thoracic Society Disparities in Healthcare Group. An official American Thoracic Society systematic review: insurance status and disparities in lung cancer practices and outcomes. Am J Respir Crit Care Med. 2010;182:1195-205.

6. Virgo KS, Little AG, Fedewa SA, Chen AY, Flanders WD, Ward EM. Safety-net burden hospitals and likelihood of curative-intent surgery for non-small cell lung cancer. J Am Coll Surg. 2011;213:633-43.

7. Lieberman-Cribbin W, Liu B, Leonine E, Flores R, Taioli E. Temporal trends in centralization and racial disparities in utilization of high-volume hospitals for lung cancer surgery. Medicine (Baltimore). 2017;96:e6573.

8. Bach PB, Cramer LD, Warren JL, Begg CB. Racial differences in the treatment of early-stage lung cancer. N Engl J Med. 1999;341:1198-205.

9. Altorki NK, Yip R, Hanaoka T, Bauer T, Aye R, Kohman L, et al. Sublobar resection is equivalent to lobectomy for clinical stage 1A lung cancer in solid nodules. J Thorac Cardiovasc Surg. 2014;147:754-62.

10. Taioli E, Yip R, Olkin I, Wolf A, Nicastri D, Henschke C, et al. Survival after sub-lobar resection for early stage lung cancer-methodological obstacles in comparing the efficacy to lobectomy. J Thorac Oncol. 2016;11: 400-6. 
11. Ettinger DS, Akerley W, Borghaei H, Chang AC, Cheney RT, Chirieac LR, et al; NCCN (National Comprehensive Cancer Network). Non-small cell lung cancer. J Natl Compr Canc Netw. 2012;10:1236-71.

12. Krantz SB, Lutfi W, Kuchta K, Wang CH, Kim KW, Howington JA. Improved lymph node staging in early-stage lung cancer in the national cancer database. Ann Thorac Surg. 2017;104:1805-14.

13. Walker GV, Grant SR, Guadagnolo BA, Hoffman KE, Smith BD, Koshy M, et al. Disparities in stage at diagnosis, treatment, and survival in nonelderly adult patients with cancer according to insurance status. J Clin Oncol. 2014;32: 3118-25.

14. Tantraworasin A, Taioli E, Liu B, Kaufman AJ, Flores RM. Underperformance of mediastinal lymph node evaluation in resectable non-small cell lung cancer. Ann Thorac Surg. 2018;105:943-9.

15. Warren JL, Klabunde CN, Schrag D, Bach PB, Riley GF. Overview of the SEER-Medicare data: content, research applications, and generalizability to the United States elderly population. Med Care. 2002;40:IV3-18.

16. Paul S, Isaacs AJ, Treasure T, Altorki NK, Sedrakyan A. Long term survival with thoracoscopic versus open lobectomy: propensity matched comparative analysis using SEER-Medicare database. BMJ. 2014;349:g5575.

17. Surveillance, Epidemiology and End Results program. Vol 2017. Available at: https://seer.cancer.gov/. Accessed July 31, 2018

18. Egevad L, Heanue M, Berney D, Fleming K, Ferlay J. Histological groups. In: Curado MP, Edwards B, Shin HR, Storm H, Ferlay J, Heanue M, et al., eds. Cancer Incidence in Five Continents, IX. Lyon, France: IARC Scientific Publications No. 160; 2007:61-6.

19. National Cancer Institute. Charlson Comorbidity Macro, 2014 Version. Available at: https://healthcaredelivery.cancer.gov/seermedicare/considerations/macro2014.html. Accessed July 31, 2018.

20. Virnig BA, Warren JL, Cooper GS, Klabunde CN, Schussler N, Freeman J. Studying radiation therapy using SEER-Medicare-linked data. Med Care. 2002;40:IV49-54.

21. Warren JL, Harlan LC, Fahey A, Virnig BA, Freeman JL, Klabunde CN, et al. Utility of the SEER-Medicare data to identify chemotherapy use. Med Care. 2002; 40:IV-55-61.

22. Cooper GS, Zhong Y, Strange KC, Dennis LK, Amini SB, Rimm AA. Agreement of Medicare claims and tumor registry data for assessment of cancer-related treatment. Med Care. 2000;38:411-21.

23. Darling GE, Allen MS, Decker PA, Ballman K, Malthaner RA, Inculet RI, et al. Randomized trial of mediastinal lymph node sampling versus complete lymphadenectomy during pulmonary resection in the patient with NO or N1 (less than hilar) non-small cell carcinoma: results of the ACOSOG Z0030 Trial. J Thorac Cardiovasc Surg. 2011;141:662-70.

24. Taioli E, Flores R. Appropriateness of surgical approach in black patients with lung cancer-15 years later, little has changed. J Thorac Oncol. 2017;12 $573-7$.

25. Soneji S, Tanner NT, Silvestri GA, Lathan CS, Black W. Racial and ethnic disparities in early-stage lung cancer survival. Chest. 2017;152:587-97.

26. Ahmed Z, Kujtan L, Kennedy KF, Davis JR, Subramanian J. Disparities in the management of patients with stage I small cell lung carcinoma (SCLC): a surveillance, epidemiology and end results (SEER) analysis. Clin Lung Cancer. 2017; 18:e315-25.

27. Jazieh AR, Kyasa MJ, Sethuraman G, Howington J. Disparities in surgical resection of early-stage non-small cell lung cancer. J Thorac Cardiovasc Surg. 2002;123:1173-6.

28. Ganti AK, Subbiah SP, Kessinger A, Gonsalves WI, Silberstein PT, Loberiza FR Jr. Association between race and survival of patients with non small-cell lung cancer in the United States veterans affairs population. Clin Lung Cancer. 2014; 15:152-8.

29. Williams CD, Salama JK, Moghanaki D, Karas TZ, Kelley MJ. Impact of race on treatment and survival among U.S. veterans with early-stage lung cancer. J Thorac Oncol. 2016;11:1672-81.

30. Esnaola NF, Ford ME. Racial differences and disparities in cancer care and outcomes: where's the rub? Surg Oncol Clin N Am. 2012;21:417-37.

31. Tohme S, Kaltenmeier C, Bou-Samra P, Varley PR, Tsung A. Race and health disparities in patient refusal of surgery for early-stage pancreatic cancer: an NCDB cohort study. Ann Surg Oncol. 2018;25:3427-35.

32. Taioli E, Liu B, Nicastri DG, Lieberman-Cribbin W, Leoncini E, Flores RM Personal and hospital factors associated with limited surgical resection for lung cancer, in-hospital mortality and complications in New York State. J Surg Oncol. 2017;116:471-81.

33. Osarogiagbon RU, Ogbata O, Yu X. Number of lymph nodes associated with maximal reduction of long-term mortality risk in pathologic node-negative non-small cell lung cancer. Ann Thorac Surg. 2014;97:385-93.

34. Osarogiagbon RU, Yua X. Nonexamination of lymph nodes and survival after resection of non-small cell lung cancer. Ann Thorac Surg. 2013;96:1178-89.

Key Words: non-small cell lung cancer, administrative database, survival, surgery, minority populations, racial disparities 


\begin{tabular}{|c|c|}
\hline $\begin{array}{l}\text { Initial Records } \\
n=537,830\end{array}$ & \multirow{2}{*}{$\begin{array}{l}\text { Excluded } \\
\text { - Date of birth or death disagreement between Surveillance Epidemiology and End } \\
\text { Results and Medicare }(n=13,885) \\
\text { - Diagnosis reporting source: autopsy or death certificate }(n=10,588) \\
\text { - Diagnosis not microscopically confirmed }(n=48,898) \\
\text { - Lung cancer not the first or only primary cancer }(n=104,698) \\
\text { - Patient with other race/ethnicity }(n=35,764)\end{array}$} \\
\hline & \\
\hline 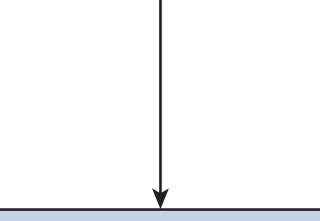 & \multirow{4}{*}{$\begin{array}{l}\text { Excluded } \\
\text { - Missing stage or non-stage I }(n=266,201) \\
\text { - Histological type other than non-small cell lung cancer }(n=2,345) \\
\text { - Missing tumor size }(n=1,200) \\
\text { - Missing or uninformative cancer diagnosis date }(n=17,511) \\
\text { - Diagnosis age }<65 \text { years; missing diagnosis month } \\
\text { - Diagnosed before } 1992 \text { or after } 2009 ; 2^{\text {nd }} \text { cancer diagnosis within } 1 \text { year } \\
\text { - Incomplete Medicare part A\&B coverage, or health maintenance organization } \\
\text { coverage for } 1 \text { year prior to diagnosis and } 1 \text { year post (or until death) }(n=11,460) \\
\text { - Missing record from Medicare National Claims History file or with non-cancer } \\
\text { directed major lung surgery ( } n=77) \\
\text { - Missing covariates (ZIP code level socioeconomic data; marital status; comorbidity) } \\
\text { ( } n=2,479)\end{array}$} \\
\hline $\begin{array}{l}\text { Black or White Patients } \\
\qquad n=323,997\end{array}$ & \\
\hline$v$ & \\
\hline Final Sample N = 22,724 & \\
\hline
\end{tabular}

FIGURE E1. Selection criteria used for study sample and reasons for exclusion.

TABLE E1. Codes used to identify treatments in Medicare

\begin{tabular}{|c|c|c|c|c|c|}
\hline Treatment & $\begin{array}{l}\text { ICD-9-CM diagnosis } \\
\text { codes }\end{array}$ & $\begin{array}{c}\text { ICD-9-CM procedure } \\
\text { codes }\end{array}$ & $\begin{array}{l}\text { HCPCS/CPT } \\
\text { codes }\end{array}$ & $\begin{array}{l}\text { Revenue center } \\
\text { codes }\end{array}$ & Medicare files \\
\hline Chemotherapy & $\begin{array}{l}\text { V58.1 } \\
\text { V66.2 } \\
\text { V67.2 }\end{array}$ & 99.25 & $\begin{array}{c}965 x x \\
965 x x \\
\text { Q0083-Q0085 } \\
\text { J9190 } \\
\text { J8610 } \\
\text { J9250 } \\
\text { J9260 } \\
\text { J9070-J9097 } \\
\text { J9060 } \\
\text { J9062 } \\
\text { J9045 }\end{array}$ & & $\begin{array}{l}\text { MedPAR } \\
\text { Outpatient, } \\
\mathrm{NCH}\end{array}$ \\
\hline Radiation therapy & $\begin{array}{l}\text { V58.0 } \\
\text { V66.1 } \\
\text { V67.1 }\end{array}$ & $92.21-92.29$ & $\begin{array}{l}77401-77499 \\
77750-77799\end{array}$ & $\begin{array}{l}0330 \\
0333\end{array}$ & $\begin{array}{l}\text { MedPAR, Outpatient, } \\
\mathrm{NCH}\end{array}$ \\
\hline Surgery & & $\begin{array}{l}32.2 x \\
32.3 x \\
32.4 x \\
32.5 x \\
32.6 x\end{array}$ & $\begin{array}{c}31640 \\
31641 \\
32440-32525 \\
32657 \\
32663 \\
32666 \\
32667 \\
32668 \\
32669 \\
32670, \\
32671 \\
32672 \\
32999\end{array}$ & & MedPAR, Outpatient, $\mathrm{NCH}$ \\
\hline
\end{tabular}

ICD-9-CM, International Classification of Diseases, Ninth Revision, Clinical Modifications; HCPCS, Healthcare Common Procedure Coding System; CPT, Current Procedural Terminology; MedPAR, Medicare Provider Analysis and Review; $N C H$, National Claims History. 
TABLE E2. Univariate and multivariable odds of receipt of treatment (yes vs no)

\begin{tabular}{|c|c|c|}
\hline Variable & $\frac{\text { Univariate }}{\text { OR }(95 \% \text { CI })}$ & $\frac{\text { Multivariable }}{\text { OR* }^{*}(95 \% \text { CI })}$ \\
\hline \multicolumn{3}{|l|}{ Race } \\
\hline White & 1.00 (Ref) & 1.00 (Ref) \\
\hline Black & $0.51(0.44-0.59)$ & $0.62(0.53-0.73)$ \\
\hline \multicolumn{3}{|l|}{ Sex } \\
\hline Male & 1.00 (Ref) & 1.00 (Ref) \\
\hline Female & $1.40(1.28-1.53)$ & $1.65(1.49-1.83)$ \\
\hline \multicolumn{3}{|l|}{ Age, y } \\
\hline $65-69$ & 1.00 (Ref) & 1.00 (Ref) \\
\hline $70-74$ & $1.08(0.93-1.24)$ & $1.06(0.91-1.22)$ \\
\hline $75-79$ & $0.81(0.70-0.93)$ & $0.79(0.68-0.91)$ \\
\hline $80-84$ & $0.51(0.45-0.59)$ & $0.53(0.46-0.61)$ \\
\hline$\geq 85$ & $0.26(0.22-0.30)$ & $0.28(0.24-0.33)$ \\
\hline \multicolumn{3}{|l|}{ Marital status } \\
\hline Married & 1.00 (Ref) & 1.00 (Ref) \\
\hline Single & $0.57(0.48-0.67)$ & $0.61(0.51-0.72)$ \\
\hline Previous marriage $\dagger$ & $0.60(0.55-0.66)$ & $0.59(0.53-0.65)$ \\
\hline \multicolumn{3}{|l|}{ Charlson score } \\
\hline 0 & $1.00(\operatorname{Ref})$ & $1.00(\operatorname{Ref})$ \\
\hline 1 & $1.19(1.07-1.33)$ & $1.31(1.17-1.47)$ \\
\hline 2 & $0.87(0.77-0.99)$ & $1.07(0.94-1.23)$ \\
\hline$\geq 3$ & $0.76(0.67-0.87)$ & $1.01(0.88-1.15)$ \\
\hline \multicolumn{3}{|l|}{ Histology } \\
\hline Adenocarcinoma & 1.00 (Ref) & 1.00 (Ref) \\
\hline Squamous & $0.70(0.63-0.78)$ & $0.8(0.72-0.89)$ \\
\hline Large cell & $0.47(0.40-0.55)$ & $0.48(0.41-0.57)$ \\
\hline Other & $0.45(0.39-0.51)$ & $0.57(0.49-0.65)$ \\
\hline \multicolumn{3}{|l|}{ Tumor size, mm } \\
\hline $0-20$ & 1.00 (Ref) & 1.00 (Ref) \\
\hline $21-30$ & $0.82(0.72-0.92)$ & $0.91(0.81-1.03)$ \\
\hline $31-50$ & $0.72(0.64-0.81)$ & $0.90(0.79-1.01)$ \\
\hline $51-70$ & $0.52(0.44-0.61)$ & $0.67(0.57-0.79)$ \\
\hline$\geq 71$ & $0.53(0.43-0.66)$ & $0.67(0.53-0.84)$ \\
\hline
\end{tabular}

TABLE E3. Univariate and multivariable odds of receipt of radiation therapy alone (yes vs no), among treated patients

\begin{tabular}{|c|c|c|}
\hline Variable & $\frac{\text { Univariate }}{\text { OR }(95 \% \text { CI })}$ & $\begin{array}{c}\text { Multivariable } \\
\text { OR }^{*}(95 \% \text { CI })\end{array}$ \\
\hline \multicolumn{3}{|l|}{ Race } \\
\hline White & 1.00 (Ref) & 1.00 (Ref) \\
\hline Black & $1.61(1.38-1.87)$ & 1.47 (1.24-1.74) \\
\hline \multicolumn{3}{|l|}{ Sex } \\
\hline Male & 1.00 (Ref) & 1.00 (Ref) \\
\hline Female & $1.12(1.03-1.22)$ & $1.18(1.07-1.30)$ \\
\hline \multicolumn{3}{|l|}{ Age, y } \\
\hline $65-69$ & 1.00 (Ref) & 1.00 (Ref) \\
\hline $70-74$ & $1.37(1.18-1.58)$ & $1.36(1.17-1.57)$ \\
\hline $75-79$ & $1.90(1.65-2.20)$ & $1.88(1.62-2.18)$ \\
\hline $80-84$ & $3.69(3.18-4.27)$ & $3.64(3.13-4.25)$ \\
\hline$\geq 85$ & 8.33 (7.04-9.85) & $8.59(7.18-10.26)$ \\
\hline \multicolumn{3}{|l|}{ Marital status } \\
\hline Married & 1.00 (Ref) & $1.00(\operatorname{Ref})$ \\
\hline Single & $1.38(1.16-1.65)$ & $1.24(1.03-1.50)$ \\
\hline Previous marriage $\dagger$ & $1.70(1.56-1.86)$ & $1.29(1.16-1.43)$ \\
\hline \multicolumn{3}{|l|}{ Charlson score } \\
\hline 0 & 1.00 (Ref) & 1.00 (Ref) \\
\hline 1 & $1.91(1.70-2.13)$ & $1.87(1.67-2.11)$ \\
\hline 2 & $2.39(2.10-2.72)$ & $2.28(1.98-2.61)$ \\
\hline$\geq 3$ & 3.33 (2.94-3.77) & $3.07(2.69-3.52)$ \\
\hline \multicolumn{3}{|l|}{ Histology } \\
\hline Adenocarcinoma & $1.00(\operatorname{Ref})$ & $1.00(\operatorname{Ref})$ \\
\hline Squamous & $1.79(1.62-1.97)$ & $1.62(1.46-1.81)$ \\
\hline Large cell & $2.93(2.53-3.41)$ & $2.84(2.41-3.33)$ \\
\hline Other & $3.33(2.94-3.78)$ & $2.78(2.43-3.17)$ \\
\hline \multicolumn{3}{|l|}{ Tumor size, mm } \\
\hline $0-20$ & $1.00(\operatorname{Ref})$ & $1.00(\operatorname{Ref})$ \\
\hline $21-30$ & $1.41(1.26-1.58)$ & $1.26(1.12-1.42)$ \\
\hline $31-50$ & $1.58(1.41-1.77)$ & $1.33(1.18-1.49)$ \\
\hline $51-70$ & $1.69(1.44-1.98)$ & $1.48(1.24-1.76)$ \\
\hline$\geq 71$ & $1.37(1.08-1.74)$ & $1.38(1.07-1.77)$ \\
\hline
\end{tabular}

$\mathrm{N}=20,555 . O R$, Odds ratio; $C I$, confidence interval. *Adjusted for all listed variables, ZIP code level socioeconomic status variables, and year of diagnosis. $\dagger$ Divorced, separated, or widowed. 
TABLE E4. Univariate and multivariable odds of receipt of chemotherapy alone (yes vs no), among treated patients

\begin{tabular}{|c|c|c|}
\hline Variable & $\begin{array}{c}\text { Univariate } \\
\text { OR }(95 \% \text { CI })\end{array}$ & $\begin{array}{c}\text { Multivariable } \\
\text { OR }^{*}(95 \% \text { CI })\end{array}$ \\
\hline \multicolumn{3}{|l|}{ Race } \\
\hline White & 1.00 (Ref) & 1.00 (Ref) \\
\hline Black & $2.90(2.11-4.00)$ & $2.46(1.74-3.49)$ \\
\hline \multicolumn{3}{|l|}{ Sex } \\
\hline Male & 1.00 (Ref) & 1.00 (Ref) \\
\hline Female & $0.89(0.71-1.12)$ & $0.99(0.77-1.27)$ \\
\hline \multicolumn{3}{|l|}{ Age, y } \\
\hline 65-69 & 1.00 (Ref) & 1.00 (Ref) \\
\hline $70-74$ & $1.03(0.73-1.45)$ & $1.04(0.74-1.47)$ \\
\hline $75-79$ & $1.25(0.89-1.76)$ & $1.25(0.89-1.77)$ \\
\hline $80-84$ & $1.44(0.99-2.10)$ & $1.31(0.89-1.93)$ \\
\hline$\geq 85$ & $1.80(1.12-2.89)$ & $1.49(0.92-2.43)$ \\
\hline \multicolumn{3}{|l|}{ Marital status } \\
\hline Married & 1.00 (Ref) & 1.00 (Ref) \\
\hline Single & $1.97(1.33-2.91)$ & $1.66(1.10-2.49)$ \\
\hline Previous marriage $\dagger$ & $1.19(0.93-1.52)$ & $1.07(0.82-1.40)$ \\
\hline \multicolumn{3}{|l|}{ Charlson score } \\
\hline 0 & $1.00(\operatorname{Ref})$ & $1.00(\operatorname{Ref})$ \\
\hline 1 & $1.56(1.17-2.09)$ & $1.52(1.13-2.03)$ \\
\hline 2 & $1.58(1.11-2.52)$ & $1.42(0.99-2.04)$ \\
\hline$\geq 3$ & $2.08(1.49-2.91)$ & $1.69(1.19-2.39)$ \\
\hline \multicolumn{3}{|l|}{ Histology } \\
\hline Adenocarcinoma & $1.00(\operatorname{Ref})$ & $1.00(\operatorname{Ref})$ \\
\hline Squamous & $1.51(1.15-2.00)$ & $1.17(0.88-1.56)$ \\
\hline Large cell & $2.88(1.98-4.21)$ & $2.73(1.85-4.03)$ \\
\hline Other & $2.86(2.06-3.97)$ & $2.06(1.47-2.88)$ \\
\hline \multicolumn{3}{|l|}{ Tumor size, mm } \\
\hline $0-20$ & 1.00 (Ref) & $1.00(\operatorname{Ref})$ \\
\hline $21-30$ & $2.13(1.45-3.13)$ & $2.12(1.44-3.13)$ \\
\hline $31-50$ & $3.56(2.48-5.12)$ & $3.39(2.35-4.90)$ \\
\hline $51-70$ & $4.84(3.14-7.45)$ & $4.67(3.01-7.26)$ \\
\hline$\geq 71$ & $6.06(3.65-10.04)$ & $6.05(3.61-10.13)$ \\
\hline
\end{tabular}

$\mathrm{N}=20,555 . O R$, Odds ratio; $C I$, confidence interval. *Adjusted for all listed variables, ZIP code level socioeconomic status variables, and year of diagnosis. $\dagger$ †ivorced, separated, or widowed.
TABLE E5. Univariate and multivariable odds of receipt of $>1$ treatment (yes vs no), among treated patients

\begin{tabular}{|c|c|c|}
\hline Variable & $\frac{\text { Univariate }}{\text { OR }(95 \% \text { CI })}$ & $\frac{\text { Multivariable }}{\text { OR* }(95 \% \text { CI })}$ \\
\hline \multicolumn{3}{|l|}{ Race } \\
\hline White & 1.00 (Ref) & 1.00 (Ref) \\
\hline Black & $1.21(1.06-1.39)$ & $1.06(0.91-1.23)$ \\
\hline \multicolumn{3}{|l|}{ Sex } \\
\hline Male & 1.00 (Ref) & 1.00 (Ref) \\
\hline Female & $0.80(0.74-0.85)$ & $0.93(0.86-1.00)$ \\
\hline \multicolumn{3}{|l|}{ Age, y } \\
\hline $65-69$ & 1.00 (Ref) & 1.00 (Ref) \\
\hline $70-74$ & $0.92(0.84-1.01)$ & $0.91(0.82-1.00)$ \\
\hline $75-79$ & $0.75(0.68-0.83)$ & $0.70(0.63-0.78)$ \\
\hline $80-84$ & $0.61(0.54-0.69)$ & $0.53(0.47-0.60)$ \\
\hline$\geq 85$ & $0.54(0.45-0.65)$ & $0.43(0.36-0.52)$ \\
\hline \multicolumn{3}{|l|}{ Marital status } \\
\hline Married & 1.00 (Ref) & 1.00 (Ref) \\
\hline Single & $0.95(0.82-1.10)$ & $0.91(0.78-1.06)$ \\
\hline Previous marriage $\dagger$ & $0.83(0.77-0.89)$ & $0.90(0.83-0.98)$ \\
\hline \multicolumn{3}{|l|}{ Charlson score } \\
\hline 0 & $1.00(\operatorname{Ref})$ & $1.00(\operatorname{Ref})$ \\
\hline 1 & $1.03(0.95-1.12)$ & $1.03(0.94-1.12)$ \\
\hline 2 & $1.00(0.90-1.11)$ & $0.95(0.85-1.06)$ \\
\hline$\geq 3$ & $0.98(0.88-1.09)$ & $0.90(0.80-1.01)$ \\
\hline \multicolumn{3}{|l|}{ Histology } \\
\hline Adenocarcinoma & 1.00 (Ref) & $1.00(\operatorname{Ref})$ \\
\hline Squamous & $1.42(1.31-1.53)$ & $1.17(1.07-1.27)$ \\
\hline Large cell & $1.53(1.33-1.75)$ & $1.45(1.25-1.67)$ \\
\hline Other & $2.06(1.84-2.29)$ & $1.77(1.58-1.98)$ \\
\hline \multicolumn{3}{|l|}{ Tumor size, mm } \\
\hline $0-20$ & $1.00(\operatorname{Ref})$ & 1.00 (Ref) \\
\hline $21-30$ & $1.64(1.48-1.82)$ & $1.72(1.55-1.91)$ \\
\hline $31-50$ & $2.89(2.63-3.19)$ & $3.01(2.73-3.33)$ \\
\hline $51-70$ & $4.27(3.76-4.86)$ & $4.41(3.86-5.03)$ \\
\hline$\geq 71$ & $5.26(4.45-6.22)$ & $5.33(4.49-6.33)$ \\
\hline
\end{tabular}

$\mathrm{N}=20,555 . O R$, Odds ratio; $C I$, confidence interval. *Adjusted for all listed variables, ZIP code level socioeconomic status variables, and year of diagnosis. $\dagger$ †ivorced, separated, or widowed. 
TABLE E6. Multivariable relative odds of receipt of treatments (compared with surgery only), among treated patients

\begin{tabular}{|c|c|c|c|}
\hline Variable & $\frac{\text { Radiation therapy only }}{\text { OR }^{*}(95 \% \mathrm{CI})}$ & $\frac{\text { Chemotherapy only }}{\text { OR }^{*}(95 \% \text { CI })}$ & $\frac{>1 \text { Treatment }}{\text { OR } *(95 \% \mathrm{CI})}$ \\
\hline \multicolumn{4}{|l|}{ Race } \\
\hline White & 1.00 (Ref) & 1.00 (Ref) & 1.00 (Ref) \\
\hline Black & $1.64(1.37-1.95)$ & $2.90(2.04-4.14)$ & $1.23(1.06-1.44)$ \\
\hline \multicolumn{4}{|l|}{ Sex } \\
\hline Male & 1.00 (Ref) & 1.00 (Ref) & 1.00 (Ref) \\
\hline Female & $1.17(1.05-1.29)$ & $1.01(0.78-1.30)$ & $0.95(0.88-1.03)$ \\
\hline \multicolumn{4}{|l|}{ Age, y } \\
\hline $65-69$ & 1.00 (Ref) & 1.00 (Ref) & 1.00 (Ref) \\
\hline $70-74$ & $1.33(1.15-1.56)$ & $1.05(0.74-1.49)$ & $0.94(0.85-1.03)$ \\
\hline $75-79$ & $1.75(1.51-2.04)$ & $1.24(0.87-1.75)$ & $0.76(0.68-0.84)$ \\
\hline $80-84$ & $3.30(2.82-3.87)$ & $1.43(0.97-2.10)$ & $0.66(0.58-0.75)$ \\
\hline$\geq 85$ & $8.15(6.77-9.82)$ & $2.26(1.38-3.70)$ & $0.75(0.62-0.91)$ \\
\hline \multicolumn{4}{|l|}{ Marital status } \\
\hline Married & 1.00 (Ref) & 1.00 (Ref) & 1.00 (Ref) \\
\hline Single & $1.24(1.02-1.51)$ & $1.69(1.12-2.54)$ & $0.95(0.81-1.11)$ \\
\hline Previous marriage $\dagger$ & $1.27(1.15-1.41)$ & $1.10(0.84-1.44)$ & $0.94(0.87-1.03)$ \\
\hline \multicolumn{4}{|l|}{ Charlson score } \\
\hline 0 & 1.00 (Ref) & 1.00 (Ref) & 1.00 (Ref) \\
\hline 1 & $1.95(1.73-2.20)$ & $1.71(1.27-2.30)$ & $1.14(1.04-1.24)$ \\
\hline 2 & $2.33(2.03-2.69)$ & $1.63(1.14-2.35)$ & $1.08(0.96-1.21)$ \\
\hline$\geq 3$ & $3.21(2.80-3.69)$ & $2.12(1.49-3.01)$ & $1.12(0.99-1.26)$ \\
\hline \multicolumn{4}{|l|}{ Histology } \\
\hline Adenocarcinoma & 1.00 (Ref) & 1.00 (Ref) & 1.00 (Ref) \\
\hline Squamous & $1.70(1.53-1.89)$ & $1.32(0.99-1.76)$ & $1.25(1.15-1.36)$ \\
\hline Large cell & $3.40(2.87-4.01)$ & $3.92(2.65-5.82)$ & $1.85(1.59-2.15)$ \\
\hline Other & $3.64(3.16-4.19)$ & $3.32(2.36-4.66)$ & $2.35(2.08-2.65)$ \\
\hline \multicolumn{4}{|l|}{ Tumor size, mm } \\
\hline $0-20$ & $1.00(\operatorname{Ref})$ & 1.00 (Ref) & $1.00($ Ref $)$ \\
\hline $21-30$ & $1.42(1.26-1.60)$ & $2.46(1.67-3.63)$ & $1.81(1.63-2.01)$ \\
\hline $31-50$ & $1.79(1.58-2.02)$ & $4.76(3.29-6.88)$ & $3.36(3.03-3.71)$ \\
\hline $51-70$ & $2.41(2.02-2.89)$ & $8.11(5.20-12.66)$ & $5.31(4.62-6.10)$ \\
\hline$\geq 71$ & $2.50(1.93-3.25)$ & $11.40(6.75-19.25)$ & $6.53(5.44-7.83)$ \\
\hline
\end{tabular}

TABLE E7. Adjusted hazard of death in black versus white patients

\begin{tabular}{lcc}
\hline \multicolumn{1}{c}{ Model } & Adjusted HR $(\mathbf{9 5} \% \mathbf{C I})$ & $\boldsymbol{P}$ value \\
\hline Overall & $0.97(0.90-1.04)$ & .32 \\
Treated patients & $0.98(0.90-1.06)$ & .58 \\
Surgery only & $0.96(0.85-1.09)$ & .54 \\
Radiation therapy only & $0.92(0.78-1.08)$ & .30 \\
Chemotherapy only & $0.90(0.62-1.31)$ & .59 \\
$>1$ treatment & $0.96(0.81-1.12)$ & .56 \\
\hline
\end{tabular}

Adjusted for treatment, sex, age, marital status, comorbidity score, histology, tumor size, ZIP code socioeconomic variables, and year of diagnosis. $H R$, Hazard ratio; CI, confidence interval. 